\title{
Failure to Pump
}

National Cancer Institute

\section{Source}

National Cancer Institute. Failure to Pump. NCI Thesaurus. Code C63165.

Problem associated with the device which fails to start pumping. 